\title{
PHÂN TÍCH NGUYÊN NHÂN GÂY GIA TĂNG XÓI LỞ BỜ SÔNG Ở ĐỒNG BẰNG SÔNG CỦU LONG
}

\author{
Huỳnh Công Hoài ${ }^{1}$, Nguyễn Thị Bảy ${ }^{1}$, Đào Nguyên Khôi ${ }^{2}$, Trà Nguyễn Quỳnh Nga ${ }^{1}$
}

Tóm tắt: Hiện tượng sạt ở Đồng bằng sông Cưu Long (ĐBSCL) đã xảy ra tù nhiều thập kỷ tuy nhiên trong 10 năm trở lại đây hiện tượng sạt lở xảy ra nghiêm trọng và ngày càng gia tăng. Để tìm hiểu nguyên nhân làm gia tăng sụ sạt lở ở ĐBSCL, các số liệu về sạt lở được thu thập và phân tích. Kết quả cho thấy có nhiều nguyên nhân ảnh hưởng đến hiện trạng sạt lở như do địa chất, hình thái sông, chế độ thưy lực, chế độ phù sa bùn cát, khai thác cát, giao thông thưy, xậy dựng ha tầng. Tuy nhiên tù̀ số liệu phân tích cho thấy tù năm 2012 khi các hồ chứa trên dòng chính Mekong đi vào hoạt động, thể tích tích nước tích lại trong các hồ chưa đã gia tăng tù 920 triệu khối lên 16370 triệu khối. Cũng tù̀ thời điểm đó diễn biến sạt lở ở ĐBSCL cũng bắt đầu gia tăng tù dưới 100 điểm tăng dần cho đến nay trên 600 điểm sạt. Song song với thời gian tích nước ở các hồ chứa thượng nguồn, số liệu đo đạt cũng cho thấy lương phù sa bùn cát về ĐBSCL giảm đáng kể, đặc biệt ở Tân Châu giảm đến $50 \%$ so với trước 2012. Điều này cho thấy việc thiếu hụt phù sa bùn cát do phù sa bùn cát tích tụ trong các hồ chứa trên dòng chính sông Mekong có nhũng mối liên hệ chặt chẽ đến sự gia tăng xói lở ở ĐBSCL. Bên cạnh đó hiện trạng khai thác cát bùa bãi làm sụ thiếu hụt phù sa bùn cát thêm trầm trọng và tạo ra sụ mất ổn định cho lòng sông cũng tác động làm gia tăng sụ xói lở. Từ khóa: Bờ sông, sạt lở, Đồng bằng sông Cửu Long, phù sa bùn cát, thủy lục, hình thái sông, khai thác cát.

Ban Biên tập nhận bài: 08/06/2019 Ngày phản biện xong: 12/07/2019 Ngày đăng bài: 25/07/2019

\section{Giới thiệu}

Đồng bằng sông Cửu Long (ĐBSCL) là một đồng bằng non trẻ được hình thành cách đây 7000 năm. Quá trình diễn biến hình thành ĐBSCL có thể mô tả như trên hình 1 .

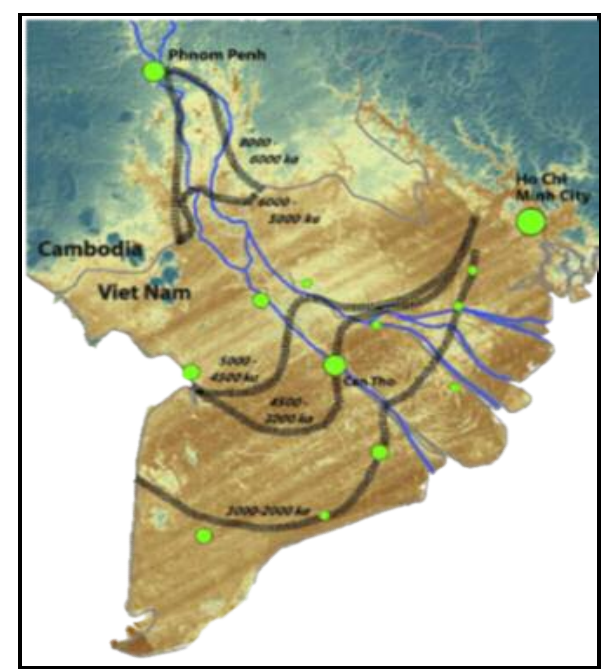

Hình 1. Quá trình hình thành thành ĐBSCL [5]
Cách đây 7000 năm mực nước biển lên đến Phnom Penh, toàn bộ ĐBSCL chưa hình thành, sau đó ĐBSCL bắt đầu được bồi đắp bởi phù sa từ sông Mekong đổ về và dòng phù sa ven bờ từ phía bắc biển Đông chảy về. Đến cách đây 3000 năm thì ĐBSCL bồi đắp đến Cần Thơ và đến cách đây 2000 năm thì ĐBSCL có hình hài như ngày nay. Với quá trình hình thành từ phù sa của sông và biển nên toàn bộ ĐBSCL đều có nền địa chất yếu, có nguồn gốc trầm tích sông biển và đầm lầy, đây cũng là nguyên nhân chính dẫn đến hiện tượng xói lở ở ĐBSCL.

Bên cạnh tính chất đặc thù của nền địa chất ở ĐBSCL, chế độ dòng chảy trong sông, ảnh hưởng của thủy triều, cùng với tác động của con người cũng là những tác nhân quan trọng gây ra xói lở bờ sông. Theo số liệu thu thập của chúng tôi, hiện tại trên sông Tiền có trên 202 điểm sạt với tổng chiều dài 218 km, sông Hậu có trên 90

${ }^{1}$ Đại hoc Bách Khoa TP. Hồ Chí Minh

${ }^{2}$ Đại hoc Khoa hoc Tự Nhiên TP. Hồ chí Minh

Email:hchoai@gmail.com 
điểm sạt với tổng chiều dài $183 \mathrm{~km}$ và khu vực tỉnh Cà Mau có 61 điểm sạt với tổng chiều dài $150 \mathrm{~km}$ (Hình 2). Nếu xét trên toàn bộ sông rạch ở ĐBSCL thì tổng số điểm sạt lên đến 665 điểm với tổng chiều dài $1048 \mathrm{~km}$.

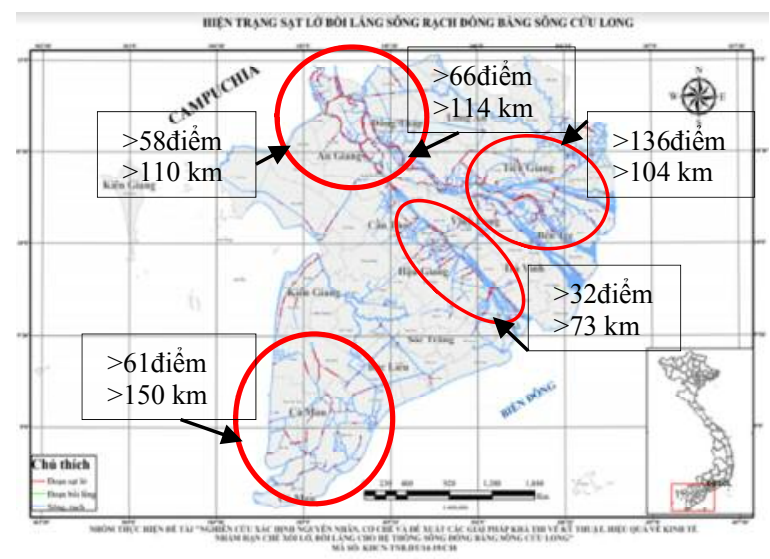

Hình 2. Vị trí các điểm sạt lở chính ở ĐBSCL

Vấn đề sạt lở ở ĐBSCL xảy ra từ nhiều thập kỷ, tuy nhiên hiện tượng sạt lở trong thời gian 10 năm trở lại đây đã xảy ra càng lúc càng nghiêm trọng và tốc độ sạt lở càng lúc càng gia tăng. Trong bài này chúng tôi sẽ dựa vào các số liệu thu thập để phân tích các yếu tố ảnh hưởng đến sạt lở lòng sông và chỉ ra những tác động làm cho hiện tượng sạt lở tại ĐBSCL ngày càng xảy ra nhiều hơn.

\section{Những nguyên nhân gây sạt lở sông rạch ở ĐBSCL}

Hiện tượng sạt lở trên sông rạch ở ĐBSCL đã được nghiên cứu khá nhiều [1], [3], [5], [7] và chỉ ra 7 nguyên nhân ảnh hưởng đến diễn biến sạt lở bờ sông như sau:

- Địa chất;

- Địa hình - hình thái sông;

- Chế độ thủy lực;

- Chế độ phù sa bùn cát;

- Khai thác cát;

- $\quad$ Giao thông thủy;

- Xây dựng cơ sở hạ tầng.

\section{1. Địa chất}

ĐBSCL được hình thành trên nền địa chất chủ yếu có nguồn gốc trầm tích sông, biển và đầm lầy. Trong nghiên cứu [2] khảo sát địa chất dọc sông Tiền cho đặc trưng của lòng sông như như hình 3, ở Hồng Ngự, An Long, Sa Đéc, Mỏ
Cày là sét $(\mathrm{d}<0,0015 \mathrm{~mm})$, Tân Châu, Mỹ Thuận là bùn sét $(0,0015<\mathrm{d}<0,003 \mathrm{~mm})$ và Bến Tre, Ba Tri là sét. Ngoài ra trong một hố khoan khảo sát địa chất ở kênh Long Xuyên Rạch Giá cho thấy trong lớp đất từ $0-4 \mathrm{~m}$ chủ yếu là đất sét pha có đường kính hạt từ 0,002 $0,075 \mathrm{~mm}$. Theo biểu đồ Hjulstrom-Sundborg [2] cho thấy với cỡ hạt từ $0,002-0,075 \mathrm{~mm}$ thì với dòng chảy có vận tốc lớn hơn $0,005 \mathrm{~m} / \mathrm{s}$ có khả năng mang các hạt di chuyển và nếu vận lớn hơn $0,3 \mathrm{~m} / \mathrm{s}-0,4 \mathrm{~m} / \mathrm{s}$ thì các hạt bùn cát với kích thước trên có khả năng bị tách ra khỏi đáy theo dòng chảy.

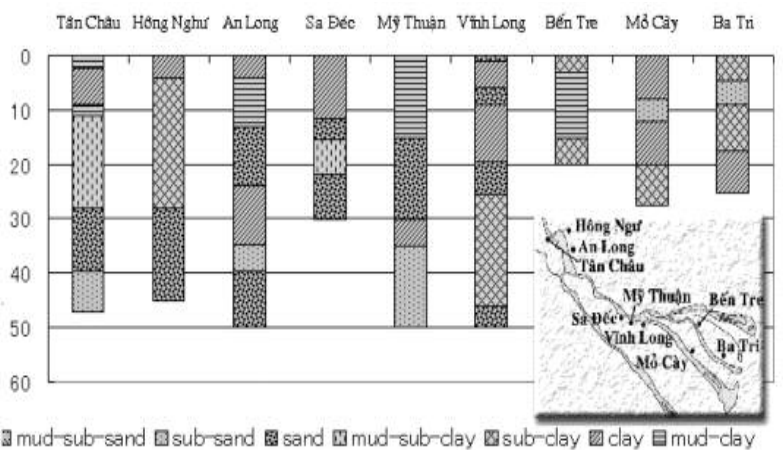

Hình 3. Tính chất lòng sông Tiền [2]

Theo các số liệu dòng chảy trên hệ thống sông Tiền và sông Hậu phân bố trong mùa lũ và mùa kiệt như Bảng 1 , vận tốc trung bình trong sông dao động từ $0,5-1,2 \mathrm{~m} / \mathrm{s}$ đều có khả năng tách các hạt bùn cát ra khỏi đáy gây xói lở. Do đó với nền địa chất đặc thù của ĐBSCL hiện tượng xói lở lòng dẫn tất yếu sẽ xảy ra thường xuyên không những trong mùa lũ mà còn trong những thời gian còn lại.

Bảng 1. Phân bố vận tốc trên sông Tiền và sông Hậu

\begin{tabular}{|c|c|c|c|c|c|}
\hline $\begin{array}{l}\mathrm{T} \\
\mathrm{T}\end{array}$ & Tên sông & $\begin{array}{l}\text { Vận tốc } \\
\text { cực đại } \\
(\mathrm{m} / \mathrm{s})\end{array}$ & $\begin{array}{l}\text { Vận tốc } \\
\text { cực tiểu } \\
(\mathrm{m} / \mathrm{s})\end{array}$ & $\begin{array}{c}\text { Vận tốc } \\
\text { trung } \\
\text { bình } \\
(\mathrm{m} / \mathrm{s})\end{array}$ & $\begin{array}{l}\text { Thời } \\
\text { gian }\end{array}$ \\
\hline \multirow{2}{*}{1} & $\begin{array}{l}\text { Sông } \\
\text { Tiền - }\end{array}$ & $1,8-2,3$ & $0,2-0,3$ & 1,2 & $\begin{array}{l}\text { Mùa } \\
\text { lũ }\end{array}$ \\
\hline & $\begin{array}{c}\text { trạm Tân } \\
\text { Châu }\end{array}$ & $1,2-1,3$ & $0,05-0,1$ & 0,7 & $\begin{array}{l}\text { Mùa } \\
\text { kiệt }\end{array}$ \\
\hline \multirow[b]{2}{*}{2} & $\begin{array}{l}\text { Sông } \\
\text { Hậu - }\end{array}$ & $1,7-2,0$ & $0,1-0,2$ & $0,8-0,9$ & $\begin{array}{c}\text { Mùa } \\
\text { lũ }\end{array}$ \\
\hline & $\begin{array}{l}\text { trạm } \\
\text { Châuu } \\
\text { Đốc }\end{array}$ & $0,8-1,2$ & $0,05-0,1$ & 0,5 & $\begin{array}{l}\text { Mùa } \\
\text { kiệt }\end{array}$ \\
\hline
\end{tabular}




\section{BÀI BÁO KHOA HỌC}

\section{2. Địa hình - Hình thái sông}

Hệ thống sông ĐBSCL bao gồm hai sông chính là sông Tiền, sông Hậu và một mạng lưới sông nhánh và kênh đào chằng chịt (Hình 4).

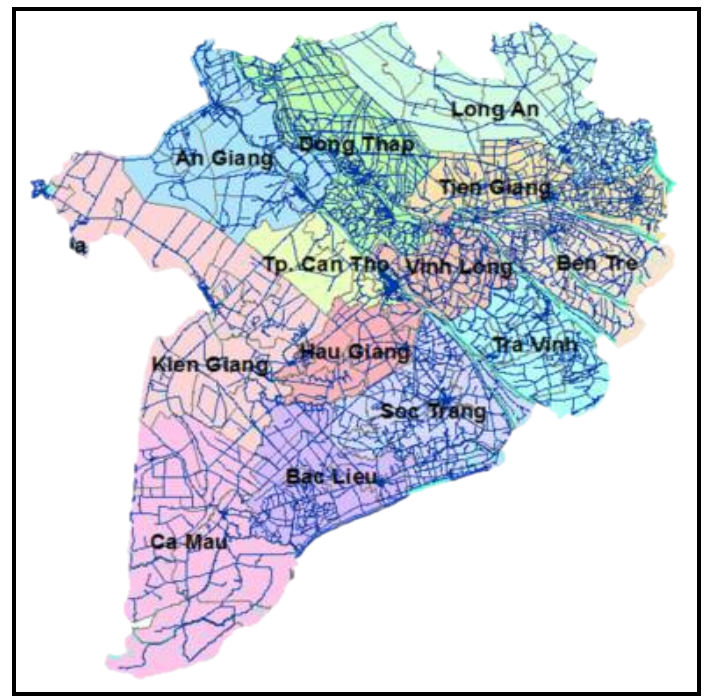

Hình 4. Mạng luới sông rạch

Ngoài ra trên sông Tiền và sông Hậu còn có nhiều cù lao làm thay đổi cục bộ dòng chảy. Theo phân tích của Dave Rosgen [6] từ việc khảo sát của 100 con sông tiêu biểu, cho thấy đối với những con sông trên nền đất sét và bùn, có độ dốc nhỏ hơn 0,02 và tỷ số độ cong (sinuosity) giữa chiều dài uốn khúc của sông trên chiều dài thẳng giữa 2 đầu sông $\mathrm{L} / \mathrm{L}^{\prime}>1,2$ đều có $\mathrm{xu}$ hướng xói bên bờ lõm và bồi bên bờ lồi. Khảo sát các đoạn sông trên sông Tiền và sông Hậu, khá nhiều đoạn sông có tỷ số độ cong L/L' > 1,2 như đoạn sông cù lao $\mathrm{Ba}$ - Châu Đốc có $\mathrm{L} / \mathrm{L}^{\prime}=$ 1,2 (Hình 5) và đoạn sông Năng Cù - phà Mường Thanh có $\mathrm{L} / \mathrm{L}^{\prime}=1,32$ (Hình 6) từ phân tích ảnh vệ tinh đều thấy bị xói bên bờ lõm. Trên sông Tiền cũng khá nhiều đoạn sông có tỉ số độ cong L/L'> 1,2 như đoạn cù lao Long Khánh đến cù lao $\mathrm{Ma}$ có $\mathrm{L} / \mathrm{L}^{\prime}=1,71$ (Hình 7) cũng cho thấy phía bờ lõm bị xói. Các đoạn sông nhánh cũng có khá nhiều đoạn sông uốn khúc có tỷ số độ cong lớn hơn 1,2 như đoạn rạch Ông Chưởng có tỉ số $\mathrm{L} / \mathrm{L}^{\prime}=1,5$ và cho thấy bị xói bên bờ lỏm (Hình 8).

Ngoài ra sự hiện hữu các cù lao trên sông Tiền và sông Hậu cũng gây ra sự bồi xói cục bộ ở đầu và cuối cù lao.

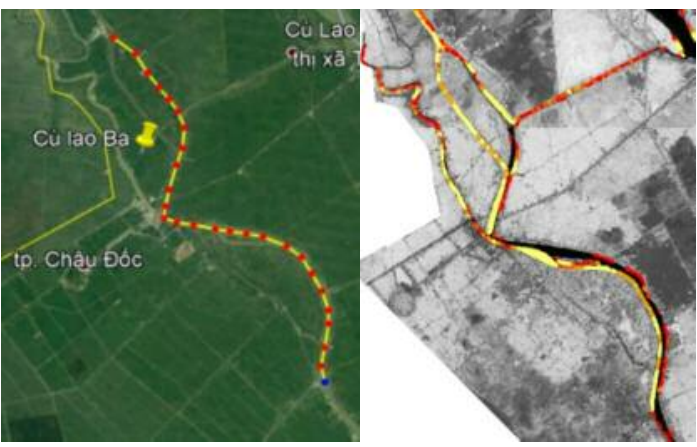

Hình 5. Đoạn sông cù lao Ba-Châu Đốc và vị trí bị xói (Tù ảnh vệ tinh - màu đỏ)

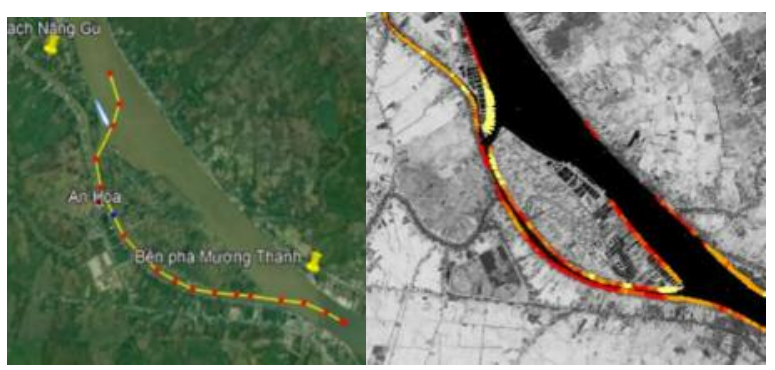

Hình 6. Đoạn sông Năng Cù-phà Muờng

Thanh và vị trí bị xói (Tù ảnh vệ tinh - màu đỏ)

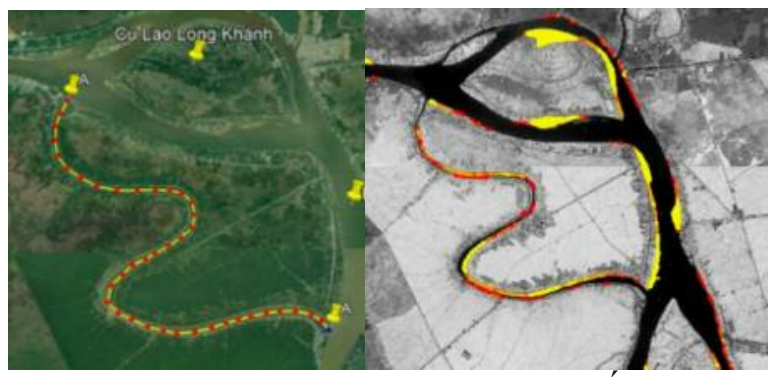

Hình 7. Đoạn cù lao Long Khánh đến cù lao Ma và vị trí bị xói (Tù ảnh vệ tinh - màu đỏ)

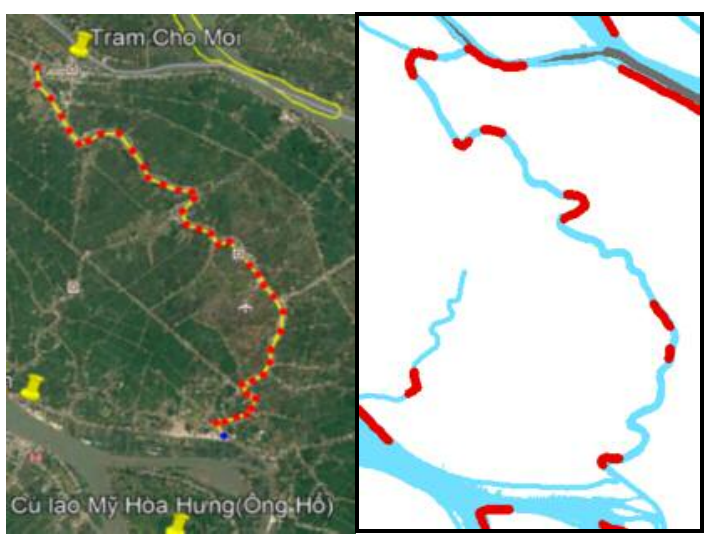

Hình 8. Đoạn sông nhánh rạch Ông Chưởng và vị trí bị xói (tù số liệu khảo sát) 
Đối với các cù lao ở thượng nguồn không bị ảnh hưởng của thủy triều đều bị xói ở đầu cù lao và bồi ở cuối cù lao như cù lao $\mathrm{Ba}$, cù lao Long Khánh, cù lao Ông Hổ, cù lao Ma... đối với cù lao nằm ở hạ lưu khu vực ảnh hưởng thủy triều thì có thể bồi xói ở hai đầu cù lao (Hình 9).

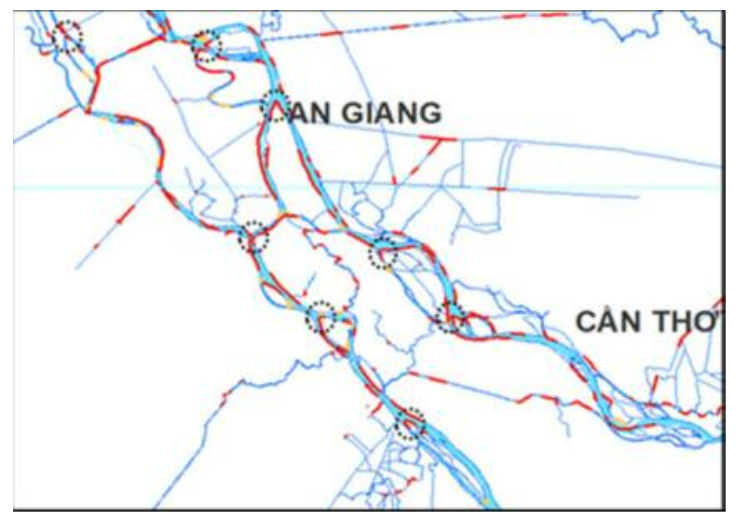

Hình 9. Các vị trí đầu cù lao bị xói

Như vậy với tính chất hình thái sông ở ĐBSCL như hiện nay, hiện tượng xói lở xảy ra phổ biến từ nhiều thập kỷ qua là điều hiển nhiên.
Dòng chảy trong hệ thống sông ĐBSCL chịu ảnh hưởng của dòng chảy thượng nguồn của sông Mekong, ảnh hưởng triều của biển Đông và biển Tây nên có thể chia chế độ thủy lực của hệ thống sông ĐBSCL ra làm 3 khu vực. Khu vực ảnh hưởng dòng chảy thượng nguồn và chịu ảnh hưởng lũ bao gồm tỉnh An Giang, một phần tỉnh Kiên Giang, tỉnh Đồng Tháp và Long An. Khu vực trung gian chịu một phần ảnh hưởng lũ thượng nguồn và ảnh hưởng thủy triều bao gồm một phần tỉnh An Giang phía tây sông Hậu, Hà Tiên và một phần tỉnh Đồng Tháp. Khu vực ảnh hưởng chính của thủy triều bao gồm các tỉnh ven bờ biển như Cà Mau, Bạc Liêu, Sóc Trăng, Trà Vinh, Bến Tre...

Hình 10 cho thấy mực nước trên sông Tiền và sông Hậu bị ảnh hưởng của thủy triều đến Cần Thơ và Mỹ Thuận, sau đó giảm dần đến Châu Đốc và Tân Châu vào mùa lũ (tháng 9,10,11) ảnh hưởng đến Cần Thơ và Mỹ Thuận.

\subsection{Chế độ thủy lục}

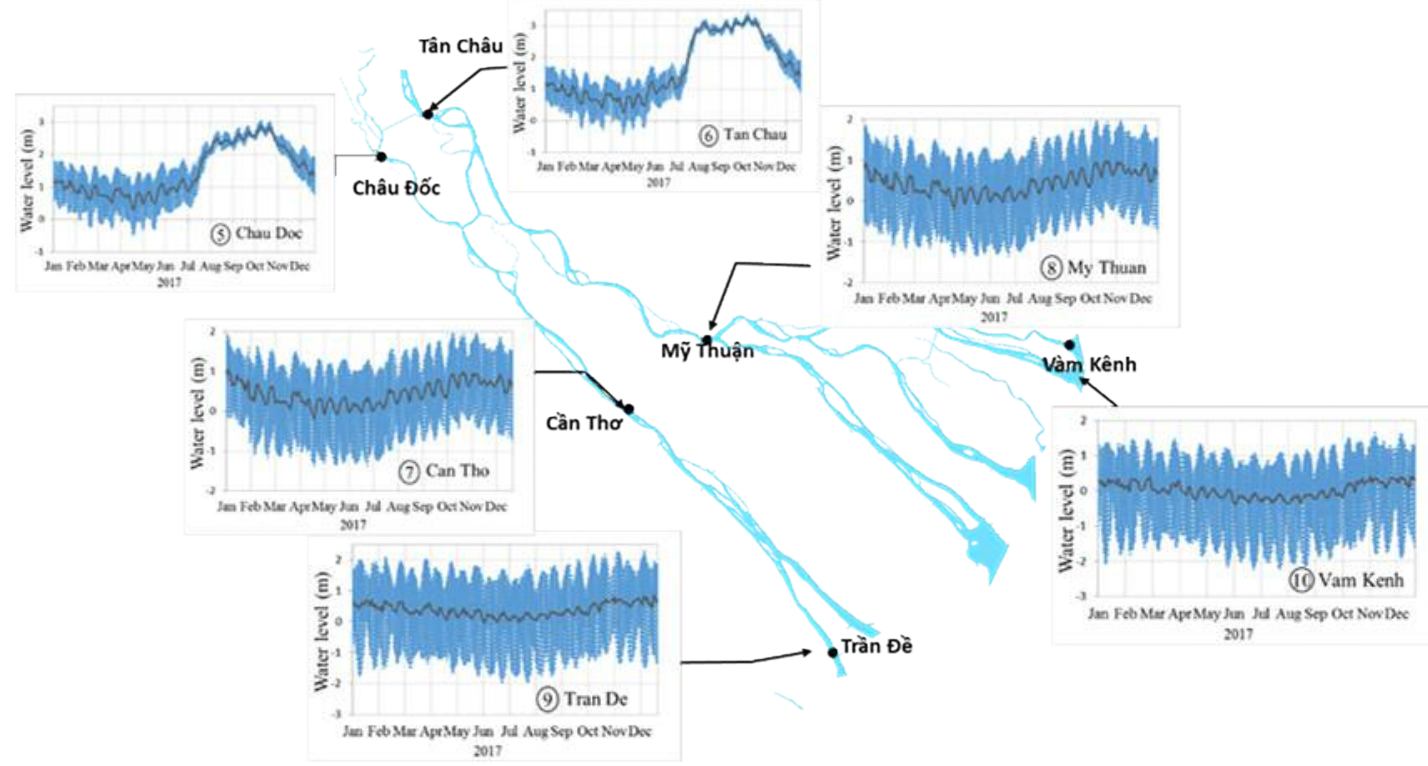

Hình 10. Mực nước dọc theo sông Tiền và sông Hậu năm 2017

Chênh lệch mực nước mùa khô và mùa lũ tại Tân Châu và Châu Đốc lên đến 3,5 m, điều này ảnh hưởng rất lớn đến sạt lở trên khu vực này. Vào mùa lũ do dòng chảy có vận tốc lớn tác động vào bờ làm xói lở bờ sông, mái dốc bờ sông càng lúc càng dốc, nhưng do mùa lũ mực nước ngầm dâng cao đồng thời mực nước trên sông cũng cao nên áp lực nước ngầm gần như bằng không. Ngoài ra đất ngậm nước và độ kết dính trong đất gia tăng làm cho mái dốc giữ được ổn định. Sau mùa lũ, đầu mùa khô mực nước sông hạ thấp, trong khi mực nước ngầm hạ thấp rất chậm làm chênh lêch mực nước ngầm và mực nước sông lớn, áp lực nước ngầm gia tăng trên 
mái dốc, đồng thời đất không còn ngậm nước, độ kết dính cũng giảm đi, tuy nhiên chưa đủ nhỏ để mái dốc mất ổn định. Đến đầu mùa mưa lớp đất khô lại bị thấm nước, đất bị nhão ra, độ kết dính càng giảm đi, lúc này các khối đất sát bờ sẽ mất ổn định và trượt xuống lòng sông [2] (Hình 11). Dựa trên số liệu khảo sát trong 10 năm trở lại đây cho thấy hiện tượng này xảy ra khá phổ biến. Gần 50\% điểm sạt lở ở ĐBSCL xảy ra vào đầu mùa mưa và sau đó số điểm sạt lở giảm đi. Hình 12 cho thấy bắt đầu mùa mưa vào tháng 5 và 6 là tháng có số điểm sạt lở gia tăng đột biến, chiếm gần $50 \%$ số điểm sạt trong các tháng còn lại.

\subsection{Chế độ phù sa bùn cát}

Nguồn phù sa bùn cát cung cấp cho hệ thống sông ở ĐBSCL chủ yếu từ thượng nguồn sông

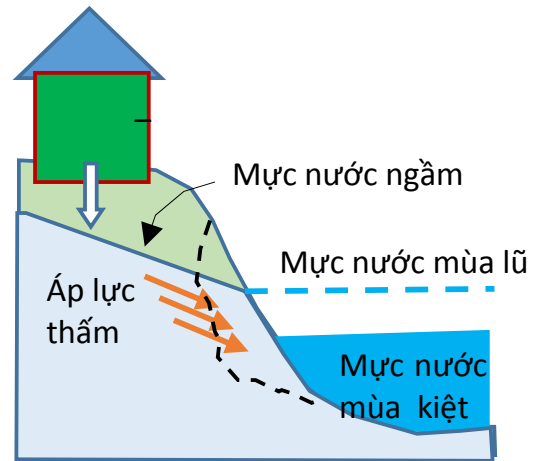

Hình 11. Áp lực nước ngầm gây trựt trên mái dốc

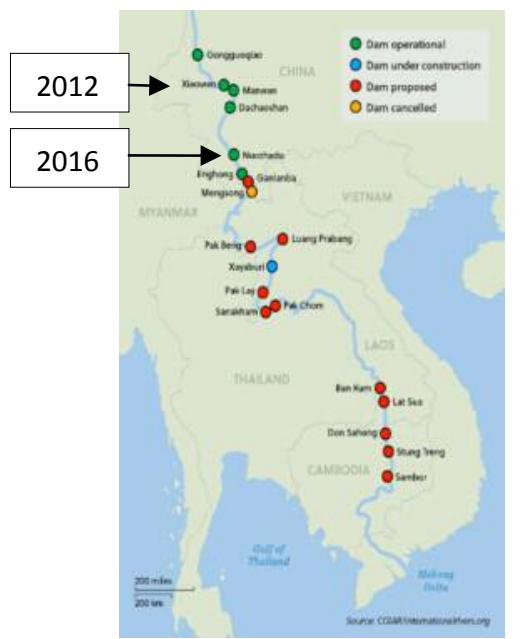

Mekong đưa về. Theo thống kê của Ủy ban sông Mekong hiện nay trên hệ thống sông Mekong có 56 nhà máy thủy điện [9], trong đó trên dòng chính có 6 nhà máy thủy điện đã hoàn thành và đưa vào sử dụng (Hình 13). Hầu hết các nhà máy hồ chứa được xây dựng trên phần đất của Trung Quốc. Trong đó đáng chú ý nhất là 2 hồ chứa Xiaowan hoàn thành năm 2012 có tổng lượng nước tích trong hồ lên đến 14560 triệu khối và hồ chứa Nuozhadu hoàn thành năm 2016 có tổng lượng nước tích trong hồ lên đến 23703 triệu khối. Hình 13 cho thấy trong năm 2012 và năm 2016 thể tích nước tích lại trong hồ Xiaowan và Nouzhadu lớn gấp nhiều lần so với các hồ chứa khác đã đi vào hoạt động trong các năm 1993 , 2002, 2013.

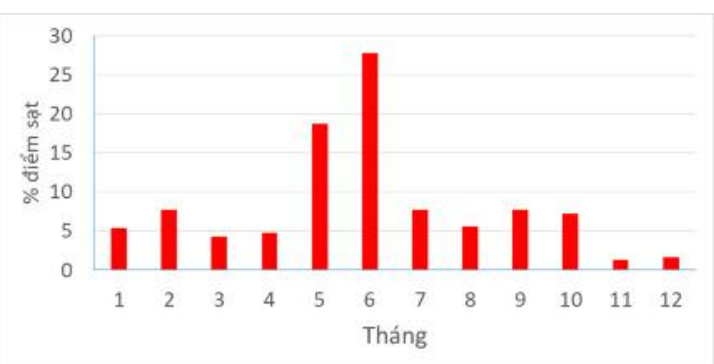

Hình 12. Số điểm xảy ra sạt lở trong năm

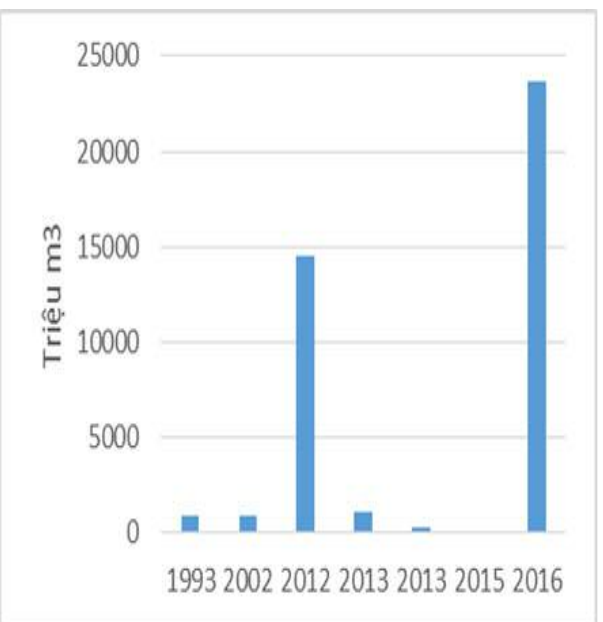

Hình 13. Vị trí các nhà máy thủy điện trên dòng chính sông Mekông và thể tích nước tích trũu trong hồ theo các năm

Với số lượng nước được giữ lại trong hồ sẽ kèm theo số lượng phù sa bùn cát bị lắng đọng lại, nguồn phù sa bùn cát về hạ du sông Mekong sẽ giảm đáng kể.

Theo số liệu thu thập tại trạm Tân Châu và Châu Đốc cho thấy trong năm 2008 tức trước 
thời gian các hồ chứa ở thương lưu Mekong tích nước, lượng phù sa về Châu Đốc là 6,71 triệu tấn và Tân Châu 59,82 triệu tấn (Hình 14). Năm 2017 tổng phù sa về Châu Đốc là 5,28 triệu tấn và Tân Châu là 38,84 triệu tấn, như vậy lượng phù sa bùn cát đã giảm đi $1 / 3$, chỉ còn $2 / 3$ lượng phù sa bùn cát so với thời gian trước khi 2 hồ chứa khổng lồ Xiaowan và Nuozhadu đi vào hoạt động. Sự thiếu hụt phù sa bùn cát làm cho dòng chảy mùa lũ gia tăng vận tốc, bào mòn lòng dẫn, các hố xói không còn được lấp bởi nguồn phù sa như trước đây. Sự xói lở tất yếu sẽ xảy ra mãnh liệt hơn.

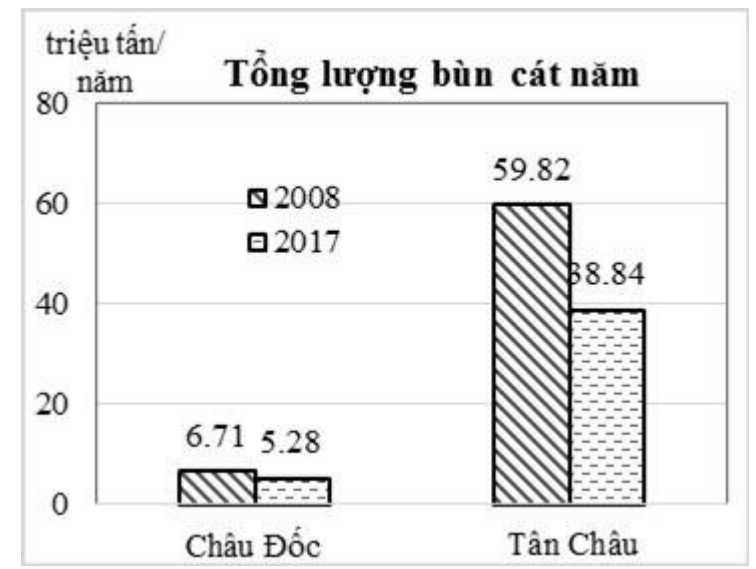

Hình 14. Lương bùn cát năm ở Châu Đốc và

\section{Tân Châu}

\subsection{Khai thác cát}

Những tác động của việc khai thác cát đến sự xói lở như sau:

- Thay đổi dòng chảy vốn đã ổn định;

- Thiếu hụt bùn cát bù đắp làm các hố khai thác phát triển không kiểm soát được;

- Khai thác quá gần bờ hoặc công trình trên sông làm mất ổn định gây lún sụp.

Lượng khai thác cát không những ở ĐBSCL mà xảy ra trên toàn bộ sông Mekong như trình bày trong Hình 15 . Theo [10] tổng lượng cát khai thác trung bình hàng năm của các nước dọc theo sông Mekong trong Bảng 2.

Việt Nam có khối lượng khai thác cát đứng hạng thứ 2 sau Cambodia và tổng lượng cát khai thác trên hạ lưu sông Mekong là 31,079 triệu khối.

Việc khai thác cát gây nên sạt lở bờ sông đã được chứng minh bởi nhiều nhà khoa học [11].
Ngoài ra việc khai thác cát tràn lan không nằm trong qui hoạch gây tác hại nhiều hơn nữa. Những vị trí khai thác này thường nằm gần bờ, sau khi khai thác để lại những hố sâu sát mái dốc bờ nên rất dễ làm bờ sông mất ổn định.

Trong nghiên cứu [7] đã cho thấy chỉ riêng trên sông Hậu đoạn chảy qua tỉnh An Giang khi khảo sát 6 điểm khai thác cát được cấp phép thì hết 3 điểm khai thác ngoài khu vực cấp phép.

Khi một lượng lớn bùn cát trên sông bị mất do khai thác dẫn đến sự mất cân bằng bùn cát trong dòng chảy gia tăng, sự xói lở xảy ra càng nhiều hơn là điều tất yếu.

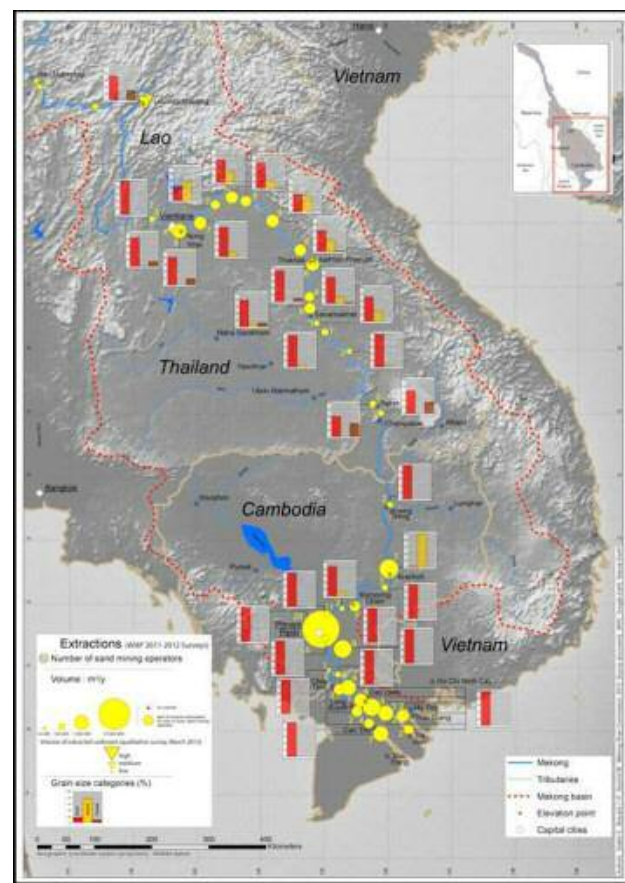

Hình 15. Vị trí khai thác cát trên sông Mekong [10]

Bảng 2. Lượng cát khai thác trung bình hàng năm trên sông Mekong [10]

\begin{tabular}{ccccc}
\hline Nước & Lào & $\begin{array}{c}\text { Thái } \\
\text { Lan }\end{array}$ & $\begin{array}{c}\text { Cam- } \\
\text { bodia }\end{array}$ & $\begin{array}{c}\text { Việt } \\
\text { Nam }\end{array}$ \\
\hline $\begin{array}{c}\text { Triệu } \\
\text { khối }\end{array}$ & 0,904 & 3,677 & 18,748 & 7,750 \\
\hline
\end{tabular}

\subsection{Giao thông thủy}

ĐBSCL có một thống kênh rạch chằng chịt, do đó giao thông thủy đóng một vai trò quan trọng trong sinh hoạt hàng ngày. Với cấu tạo địa chất ĐBSCL rất yếu do đó ảnh hưởng của sóng tàu làm xói lở là không tránh khỏi.

Sóng tàu ở ĐBSCL có biên độ và chu kỳ sóng nhỏ chiều cao $\mathrm{H}<0,5 \mathrm{~m}$, và chu kỳ $\mathrm{T}<1,5 \mathrm{~s}$ do 
đó tần số giao động lớn (Hình 16). Do tần số dao động sóng lớn nên khả năng làm tách rời các hạt bùn cát và gây xói ở bờ sông khá phổ biến. Tuy sóng tàu thường xuất hiện trong một giai đoạn ngắn nhưng lập lại thường xuyên. Sóng tàu thường gây xói lở lưng chừng mái dốc, phát triển chậm nhưng liên tục và phổ biến nên ảnh hưởng của sóng tàu là một yếu tố khá quan trọng đến xói lở trong các hệ thống kênh rạch nhỏ.

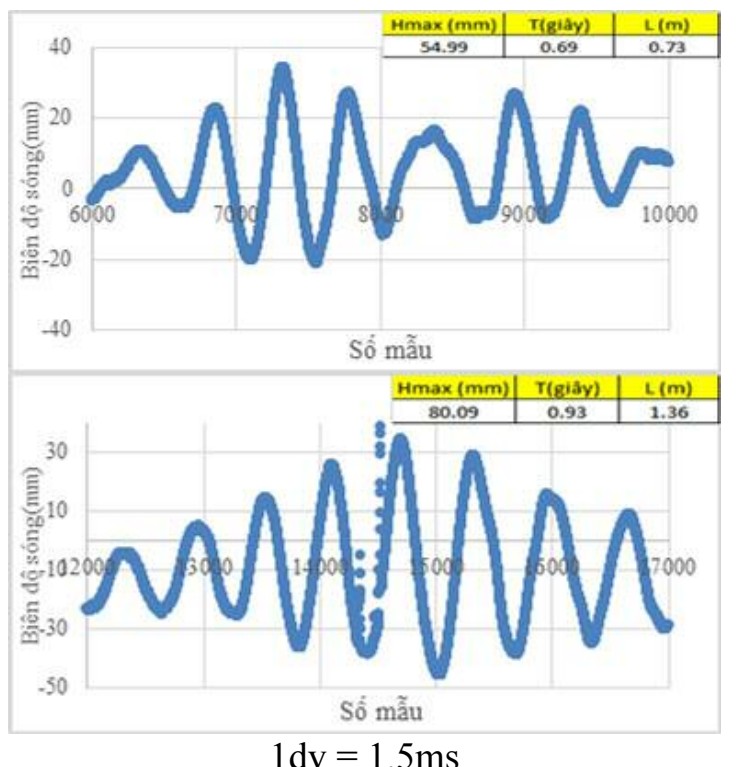

Hình 16. Mẫu sóng tàu đo tại kênh Long Xuyên - Rach Giá

\subsection{Xây dựng cơ sở ha tầng}

Xây dựng hạ tầng trên nền đất yếu làm gia tăng tải trọng trên bề mặt bờ sông đưa đến sạt lở là nguyên nhân trực tiếp do tác động của con người.

Sự ổn định mái dốc là do sự cân bằng của lực chống trượt gồm lực ma sát, lực dính (phụ thuộc vào tính chất cơ lý của đất) và lực gây trượt gồm trọng lượng khối đất, tải trọng trên bề mặt và áp lực thấm. Do đó khi một trong những lực gây trượt gia tăng sẽ làm mất sự cân bằng và mái dốc sẽ trượt.

Chỉ cần khảo sát 7 vị trí sạt lở nghiêm trọng ở An Giang từ bản đồ sạt lở trực tuyến [12] cũng cho thấy hết 5 vị trí xảy ra sạt lở đều ở khu vực có xây dựng nhà ở hoặc đường giao thông.

Nguyên nhân gây sạt lở do xây dựng cơ sở hạ tầng có thể hạn chế nếu các khu vực dân cư và giao thông được qui hoạch tốt.

\section{Nguyên nhân tác động gây gia tăng mức độ sạt lở}

Trong phần phân tích 7 nguyên nhân gây sạt lở ở ĐBSCL có thể thấy một số nguyên nhân mang tính chất đặc thù của khu vực và biến đổi rất chậm hoặc biến động không rõ rệt như địa chất, hình thái sông, chế độ thủy lực, giao thông thủy và xây dựng cơ sơ hạ tầng. Còn lại 2 nguyên nhân trong thời gian gần đây đã có những đột biến đó là chế độ phù sa bùn cát và khai thác cát. Theo thống kê các điểm sạt lở từ năm 2000 đến 2018, Hình $17 \mathrm{a}$ cho thấy số điểm sạt lở bắt đầu gia tăng từ năm 2007, 2008 nhưng sau đó giảm dần và đến năm 2012 thì bắt đầu gia tăng liên tục cho đến nay với mức độ tăng dần đến trên 600 điểm sạt lở. Liên hệ lại với thể tích hồ chứa trên dòng chính Mekong, Hình $17 \mathrm{~b}$ cho thấy trước năm 2012 hầu như không có hồ chứa nào đi vào hoạt động, đến năm 2012 thể tích tích nước trên dòng Mekong đột biến, từ 920 triệu khối đến 16370 triệu khối, tăng lên 17,8 lần, đây là thời điểm hồ chứa nước Xiaowan đi vào hoạt động (Hình 13). Đến năm 2016 khi hồ chứa Nouzhadu bắt hoạt động, thể tích trử nước trên dòng Mekong tăng lên 41612 triệu khối, tức tăng 2,54 lần so với năm 2012 và tăng 45,2 lần so với trước năm 2012.

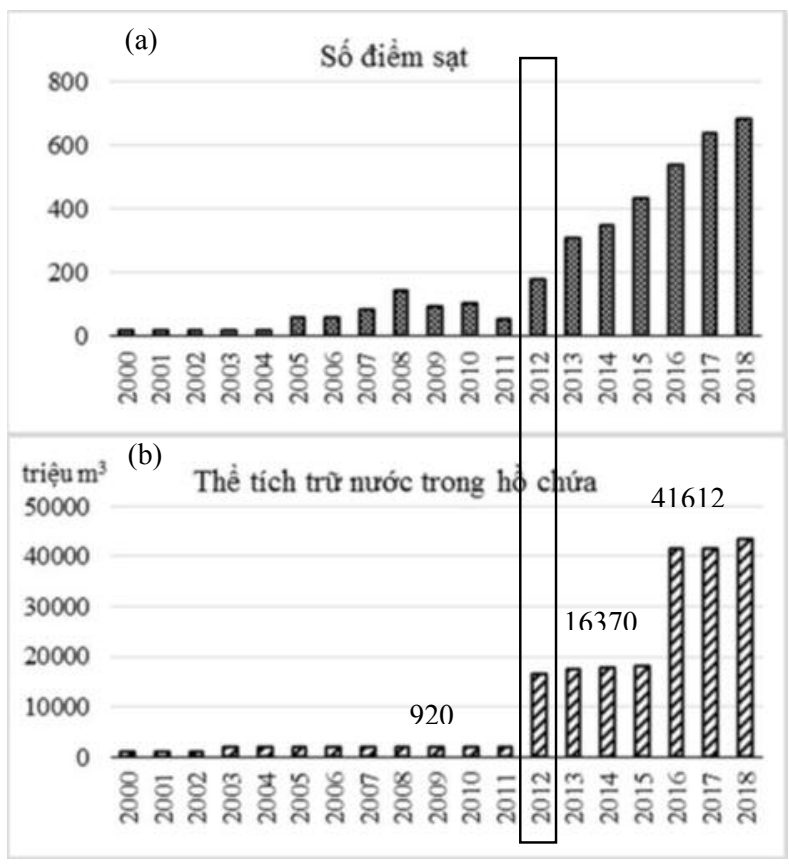

Hình 17. (a) Số điểm sạt ở ĐBSCL và (b) thể tích trũ nước trong các hồ chưa trên dòng chinh Mekong 
Từ kết quả phân tích diễn biến số điểm sạt ở ĐBSCL và diễn biến thể tích trữ nước trên dòng chính Mekong cùng với lượng phù sa suy giảm tại Châu Đốc và Tân Châu cho thấy có mối tương quan khá chặt chẽ với nhau. Trước năm 2012 số điểm sạt ở ĐBSCL có xuất hiện, tuy nhiên có năm tăng và giảm, trung bình 100 điểm 1 năm. Từ năm 2012 khi thể tích trữ nước vào các hồ chứa trên dòng chính Mekong đột biến gia tăng 17,8 lần thì ở ĐBSCL số lượng các điểm sạt bắt đầu gia tăng, sự gia tăng này liên tục xảy ra cho đến năm 2016, khi một hồ chứa trên sông Mekong xây dựng xong và đi vào vận hành, một lượng nước lớn nữa được tích lại, số lượng các điểm sạt ở ĐBSCL lại tiếp tục gia tăng. Như vậy trong vòng 7 năm thì số điểm sạt lở từ 100 điểm hàng năm đã tăng lên đến nay là trên 600 điểm.

Bên cạnh sự thiếu hụt phù sa bùn cát cho
ĐBSCL do việc tích nước của các hồ chứa thượng nguồn, việc khai thác cát bừa bãi làm tăng sự thiếu hụt bùn cát thêm trầm trọng. Ngoài ra việc khai thác cát không nằm trong các khu vực qui hoạch dẫn đến nguy cơ sạt lờ bờ càng gia tăng.

\section{Kết luận}

Sạt lở ở ĐBSCL đã được phân tích cho thấy có nhiều nguyên nhân, tuy nhiên với những số liệu thu thập được chứng tỏ sự gia tăng hiện tượng sạt lở ở ĐBSCL trong thập niên vừa qua là do tác động của 2 yếu tố chính, một là sự tích trữ nước của các hồ chứa ở dòng chính sông Mekong dẫn đến sự thiếu hụt phù sa bùn cát và hai là sự khai thác cát không được kiểm soát chặt chẽ đã làm sự thiếu hụt phù sa bùn cát thêm trầm trọng, do đó sự sạt lở bờ sông càng gia tăng.

Lời cảm ơn: Nghiên cúu này được tài trọ bởi Chuơng trình Tây Nam Bộ trong khuôn khổ đề tài mã số KHCN-TNB.ĐT/14-19/C10. Nhóm tác giả chân thành cảm ơn sụ hố trọ̣ này.

\section{Tài liệu tham khảo}

1. Bộ Nông nghiệp và Phát triển Nông thôn (2017), Báo cáo: Lún sut đất và xói lở vùng ĐBSCL: Thực trạng, nguyên nhân và định hướng giải pháp. Hội nghị chuyển đổi mô hình phát triển ĐBSCL theo hướng bền vững và thích ứng biến đổi khí hậu.

2. Delt (2003), Bank Erosion in Mekong Delta and along Red River in Vietnam. Report Mission 23 November - 6 December 2003.

3. Hjulstrom, F., (1935), Studies of the Morphological Activity of River as illustrated by the river. Fyris Bulletin, Geological Institute of Upsala, Upsala, Sweden.

4. Lê Mạnh Hùng và các tác giả (2004), Nghiên cứu dụ báo xói lở bồi lắng lòng dẫn và đề xuất các biện pháp phòng chống cho hệ thống sông ở ĐBSCL. Đề tài cấp nhà nước KC-08-15.

5. Marcello Gugliotta, Yoshiki Saito, Van Lap Nguyen, Thi Kim Oanh Ta, Rei Nakashima, Toru Tamura, Katsuto Uehara, Kota Katsuki, Seiichiro Yamamoto (2017), Process regime, salinity, morphological, and sedimentary trends along the fluvial to marine transition zone of the mixed-energy Mekong River delta, Vietnam. Continental Shelf Research, 147, 7-26.

6. Nguyễn Nghĩa Hùng và các tác giả (2015), Nghiên cứu các giải pháp khoa họ-công nghệ để điều chỉnh và ổn định các đoạn sông có cù lao đang diễn ra biến động lớn về hình thái trên sông Tiền và sông Hậu. Đề tài thuộc chương trình KH\&CN cấp nhà nước KC.08.21/11-15.

7. Rosgen, D., (1996), Applied river morphology. Woldland Hydology, Pagosa Springs, CO.

8. Viện khoa học Khí tượng Thủy văn và Biến đổi khí hậu (2015), Phân tích nguyên nhân chính gây sạt lở bờ sông Hậu tỉnh An Giang. Dự án: Điều tra khảo sát điều kiện tự nhiên-Dòng chảy, địa hình, địa chất, lòng sông nhằm xác định nguyên nhân gây sạt lở bờ sông Hậu (đoạn chảy qua An Giang) và đề xuất kế hoạch tổng thể khắc phục.

9. Liu, J.P., DeMaster, D.J., Nittrouer, C.A., Eidam, E.F., Nguyen, T.T., (2017), A seismic study of the Mekong subaqueous delta: Proximal versus distal sediment accumulation. Continental Shelf 


\title{
BÀI BÁO KHOA HỌC
}

Research, 147, 197-212.

10. Wikipedia (2019), Hydropower in the Mekong River Basin. https://en.wikipedia.org/wiki/Hydropower_in_the_Mekong_River_Basin\#cite_note-mekv33-13

11. Bravard, J.P., Marc Goichot et Stéphane Gaillot (2013). Geography of Sand and Gravel Mining in the Lower Mekong River. EchoGéo, Open Edition Journal, 26, 1-20.

12. Anthony, E.J., Brunier, G., Besset, M., Goichot, M., Dussouillez, P., Nguyen, V.L., (2015), Linking rapid erosion of the Mekong River delta to human activitie. Scientific Report, 5, 14745.

13. Bộ Nông nghiệp Phát triển Nông thôn (2018). Bản đồ sạt lở trục tuyến http://satlodbscl.phongchongthientai.vn/\#12/10.5943/105.3043/c1c2c3

\section{ANALYZING THE CAUSES PRODUCING THE RAPIDITY OF RIVER BANK EROSION IN MEKONG DELTA}

\author{
Huynh Cong Hoai ${ }^{1}$, Nguyen Thi Bay ${ }^{1}$, Dao Nguyen Khoi ${ }^{2}$, Tra Nguyen Quynh Nga ${ }^{1}$ \\ ${ }^{1}$ Ho Chi Minh City University of Technology \\ ${ }^{2} \mathrm{VNUHCM}$ - University of Science
}

\begin{abstract}
The bank erosion in Mekong delta has occurred in many decades, however in the past 10 years, the erosion has occurred seriously and rapidly. In order to find the reasons affecting the erosion increase, the data had been collected to analyze. The results show there are many factors affecting to the erosion in the river, such as geology, river morphology, hydraulic regime, sediment regime, sand mining, navigation, infrastructure construction...However, from the data analysis prove that since 2012 the reservoirs on the mainstream of Mekong river operated, the volume of water stor-ing in the reservoirs increased from 920 million of cubic meter to 16370 million of cubic meter. Also, from this moment, erosion in Mekong Delta has increased from 100 locations to over 600 locations in year 2019. During the period of the reservoirs in Mekong river store water, the measured data of sediment at Tan Chau and Chau Doc (in the boundary between Cambodia and Vietnam) showed that sediment has decreased, particularly at Tan Chau, the sediment is reducing more than 50\%comparing in the period before year 2012. It is found that the lack of sediment in flow due to the water stored in reservoirs in the mainstream of Mekong river is relative strongly to the increasing erosion in the Mekong delta. Besides, the extraction of sand in river without control produces the lack of sediment more seriously and causes the instability of river bank, that is also a factor affecting to the erosion rapidity.
\end{abstract}

Keywords: Bank erosion, Mekong Delta, sediment, hydraulics, river morphology, sand mining. 